\title{
Bumpy roads of the posted Europe: Issues of principles of conferral of competences and subsidiarity in the light of the Posted Workers Directive of the European Parliament and of the Council 2018/957
}

\begin{abstract}
The aim of the study is to analyze if the subsidiarity principle in the context of the legal solutions introduced by the Directive of the European Parliament and of the Council 2018/957 amending Directive 96/71 concerning the posting of employees in the framework of the provision of services should be considered justified and proportionate.

The arguments presented will show the opinion that the subsidiarity principle is one of the basic rules for conducting economic policy in the European Union. On this basis, it will be investigated whether policy powers should be delegated to the lowest possible level of government, close to the citizens concerned by the policy, unless there are undeniable benefits to running it at a higher level in closer policy coordination.

It should be considered if the European Commission proposal pursues a purpose other than the declared one and thus, violates the principle of proportionality. It will be proved that smart and clear rules are needed that are adapted to the rapidly growing mobility of EU businesses and citizens, which will prevent the progressive loss of competitiveness of the EU market, while accelerating social convergence and preventing illegal activities affecting intra-EU migrant workers.

The issues mentioned above and the conclusions may lead, according to the author, to the reflection on the importance of the fact that the division of competences between the Member States and the EU institutions is ultimately a political decision that arises in the context of a conflict of interest and indicates that economic analyses can only provide arguments for or against policy centralization. Furthermore, it should be noted that the integration
\end{abstract}

1 SGH Warsaw School of Economics; Faculty of Law and Administration at Warsaw University; Faculty of Law at the Maastricht University in the Netherlands; The British Law Centre at Warsaw University and the University of Cambridge, e-mail: max.jablecki@gmail.com, https://orcid.org/0000-0001-7073-9327 
is a dynamic process, and therefore, the results of the analysis regarding the justification for the application of the subsidiarity principle may lead to divergent assessments by the Member States, as the conditions of the functioning of economies are rapidly changing.

Keywords: subsidiarity, conferral of competences, posted workers, Directive 2018/957, subsidiarity principle, EU migrant workers, EU Law, public policy

JEL Classification Codes: K00, K31, L38, K33

DOI: $10.33119 / \mathrm{KSzPP} / 2020.4 .3$

\section{Wyboiste drogi delegowanej Europy — zagadnienia zasad przekazywania kompetencji i subsydiarności $w$ świetle Dyrektywy Parlamentu Europejskiego i Rady (UE) 2018/957}

\section{Streszczenie}

Celem badania jest analiza, czy zasady przekazywania kompetencji i subsydiarności w kontekście rozwiązań prawnych wprowadzonych Dyrektywą Parlamentu Europejskiego i Rady (UE) 2018/957 zmieniającą Dyrektywę 96/71 dotyczącą delegowania pracowników należy uznać za uzasadnione i proporcjonalne. Przedstawione argumenty wykazują, że zasada subsydiarności jest jedną z podstawowych zasad prowadzenia polityki gospodarczej w Unii Europejskiej. Na tej podstawie zbadano, czy uprawnienia polityczne powinny być delegowane na najniższy możliwy szczebel władzy zbliżony do obywateli, których dotyczy polityka - chyba że istnieją niezaprzeczalne korzyści z prowadzenia jej na wyższym szczeblu przy ściślejszej koordynacji.

Należy rozważyć, czy propozycja Komisji Europejskiej ma inny cel niż deklarowany, a tym samym, czy narusza ona zasadę proporcjonalności. Udowodniono, że potrzebne są inteligentne i jasne przepisy dostosowane do szybko rosnącej mobilności przedsiębiorstw i obywateli UE, które zapobiegną postępującej utracie konkurencyjności rynku UE, przyśpieszą konwergencję społeczną i uniemożliwią nielegalną działalność szarej strefy wpływającej na sytuację pracowników migrujących wewnątrz UE.

Powyższe kwestie i wnioski mogą, zdaniem autora, skłaniać do refleksji nad wagą tego, że podział kompetencji między państwami członkowskimi a instytucjami unijnymi jest ostatecznie decyzją polityczną, która pojawia się w kontekście konfliktu interesów, i wskazują, że analizy ekonomiczne mogą jedynie dostarczyć argumentów za lub przeciw centralizacji polityki. Ponadto należy podkreślić, że integracja jest procesem dynamicznym, dlatego wyniki analiz dotyczących uzasadnienia stosowania zasady subsydiarności mogą prowadzić do rozbieżnych ocen przez zainteresowane Państwa Członkowskie w czasie, w którym dynamicznie zmieniają się warunki funkcjonowania gospodarek. 
Słowa kluczowe: subsydiarność, przekazywanie kompetencji, pracownicy delegowani, Dyrektywa 2018/957, zasada pomocniczości, migrujący pracownicy UE, prawo UE, polityka publiczna

Kody klasyfikacji JEL: K00, K31, L38, K33

\section{Introduction}

Policy coordination in the European Union (hereinafter the EU) is a dynamic process. After the implementation of the single market program, the catalog of European policy areas was gradually expanded to include those that were previously the domain of the Member States. The reasons for extending the intervention of the European institutions have been explained in various ways, but from a purely economic point of view, it cannot always be considered fully justified (Gelauff, 2008: $1-2$ ). However, it should be underlined that this cannot be underestimated in the context of economic policy.

The EU appears shaped as a political union, properly defined in its legal and institutional profile. It is provided with common institutions and related attributions, with a defined balance of legislative, executive, and judicial powers, even if according to a scheme of collaboration and complementarity towards a mutual balance, rather than a separation. Competences are assigned according to the attribution and subsidiarity principles (Ciancio, 2020: 11). In this light, the subsidiarity principle is one of the basic rules for conducting economic policy in the EU. According to it, policy powers should be delegated to the lowest possible level of government, i.e., as close as possible to the citizens concerned by the policy, unless there are undeniable benefits to running it at a higher level in closer policy coordination. The division of competences between the Member States and the EU institutions is ultimately a political decision that arises under conflicts of interest (Mataija, 2009: 153).

The aim of the study is to analyze the subsidiarity principle in the context of the solutions introduced by Directive 96/71/EC concerning the posting of workers (Directive 96/71/EC of the European Parliament and of the Council of 16 December 1996 concerning the posting of workers in the framework of the provision of services [1996] OJ L 18, 21.1.1997) and assess whether recent amendments to the Directive should be considered justified and proportionate. It should be examined whether the European Commission proposal has a purpose other than the declared one, and thus, it violates the principle of proportionality. It is necessary to analyze whether the proposed amendments to the Directive are more adequate and adapted to the rapidly 
growing mobility of EU enterprises and citizens, which will prevent the progressive loss of competitiveness on the EU market, accelerate social convergence and prevent illegal activity in the grey economy affecting the situation of migrant workers within the EU and, in this way, allow for its practical implementation.

The analysis is based on the legal acts, selected official documents and materials published by the EU institutions as well as by bodies of the Member States and literature in this field. As one of the research methods, also the analysis of selected cases and judgments of the Court of Justice of the European Union on the subject is used.

\section{The reform of the 1996 Directive on posted workers}

As early judgments of the Court of Justice of the EU (hereinafter the CJEU) in the cases Manpower (Case C-35/70 Manpower v Caisse primaire d'assurance maladie de Strasbourg, 1970) and Van der Vecht (Case C-19/67 Soziale Verzekeringsbank v Van Der Vecht, 1967) show, employee posting was already a phenomenon in the late 1960s and early 1970s, even before the internal market was launched. The practice of hiring workers from a country with a "cheaper" social security scheme, with the sole purpose of posting them to a Member State with a more expensive social security regime, was at that time labeled abusive and "social dumping" (van Hoek, Houwerzijl, 2012).

The debates focused on the extent to which the Member States must be allowed or should be required to apply their mandatory wage provisions and other working conditions to workers posted to their territory. It was only after a six-year process of negotiations, deadlock, and amended proposals that the 96/71 was finally adopted (van Hoek, Houwerzijl, 2012).

After more than 20 years of Directive 96/71 on the posting of workers in the framework of the provision of services, the European institutions have recognized the need to assess whether this Act still provides the right balance between the need to promote the freedom to provide services and the need to protect the rights of posted workers. As a result of the evaluation in this regard, it was recognized that in consequence of socio-systemic transformations and improper practices of some enterprises posting employees, it is necessary to take additional measures to secure one of the main freedoms shaping the EU.

As a consequence, on 29 May 2018, the European Parliament adopted the Directive of the European Parliament and of the Council 2018/957 amending Directive 96/71 concerning the posting of employees in the framework of the provision of services (hereinafter: the amending Directive). The Member States were obliged to implement 
the amending Directive by 30 July 2020. This Directive modifies, among others, guaranteed conditions of employment of posted workers, rules of posting by temporary employment agencies, and also shortens the maximum period of posting. Employers will be required to provide posted workers with a "pay" corresponding to the law or practice of the country to which the employee is directed.

Under the new rules, "remuneration" should be interpreted in accordance with the legislation or practice of the host country. It refers to all components of the remuneration which are, under the national laws of that country, not only legislative but also executive, administrative, or collective sectoral agreements or arbitration awards - they are obligatory. As a result of changes in regulations, a Polish employer posting an employee to work in another EU country will, therefore, be obliged to provide him or her with all mandatory elements of remuneration applicable in that country, e.g., an allowance for work on holidays or bonuses.

\section{Abuse and social dumping}

The discussion on the posting of workers intensified in connection with the accession of new Member States to the EU in 2004. The first contact with the issue of posting of workers by the new Member States took place during the negotiations of the Accession Treaty.

The media systematically reported cases of violation of the rights of posted workers. Particularly noteworthy is the case of employees employed from June 2008 to October 2012 in the construction of the Flamanville nuclear power plant in France. Posting of workers began to be equated with the broadly understood migration of employees and foreigners, but also with a number of negative practices on the labor market - such as undeclared and forced labor - arousing extreme emotions.

In the broad opinion of Western European citizens, there has been a concern that the posting of workers may threaten their position in the labor market. The situation with delegation - maintaining the right proportions - began to resemble the atmosphere that took place during the debate on the adoption of the European constitution and the threat from the "Polish plumber." Western societies were threatened by the "invasion" of migrants from Eastern Europe who took jobs from local workers. Given the size of the posting in the light of the European Commission data (European Commission, Impact Assessment accompanying the document "Proposal for a Directive of the European Parliament and the Council amending Directive 96/71/ EC concerning the posting of workers in the framework of the provision of services," COM (2016) 128 final.: 55-57), in 2014 around 1.92 million employees were posted 
within the EU. Posting represents only 0.7 percent. In the scale of EU employment, that is a market segment with an exceptional growth rate. Between 2010 and 2014, the number of posted workers increased by $44.4 \%$. A significant share in the number of posted employees is occupied by Polish enterprises, which posted about 428 thousand employees in 2014. Posting concerns a range of industries, from construction to ICT companies. Given the size of the posting and its nature (the transient nature of the service), these concerns seem exaggerated (Lisicki, 2016).

\section{A yellow road to the Directive}

The amending Directive was adopted; however, the proposals for changes of the Commission in 2016 from the very beginning provoked fierce resistance presented both at the governmental level and representatives of specific industry bodies.

The proposal has encountered opposition from some EU Member States, largely in Eastern Europe. Under EU rules introduced by the Treaty of Lisbon, Member States' national parliaments can disagree with a proposal up to eight weeks after its publication. Under this "yellow card" procedure, if enough Member States express a negative opinion, the Commission must re-examine its proposal, after which it can choose to amend or withdraw its draft (Fromage, Kreilinger, 2017: 125-160). A total of one-third of the votes assigned to national parliaments requires the European Commission to review a given proposal. Two votes are assigned to each national Parliament. In a bicameral parliamentary system, each of the two chambers has one vote. The total number of votes is at 56 (54 after Brexit) (twice the number of Member States). Thus, 10 Member States have between them 20 votes, and this is sufficient to satisfy the one-third requirement.

This requirement was fulfilled because eleven Member States' parliamentary chambers (22 votes) had criticized the proposed changes on the grounds of conflict with the right to subsidiarity, with the number of votes in the brackets: the Romanian Chamber of Deputies (1), the Romanian Senate (1), the Czech Chamber of Deputies (1), the Czech Senate (1), the Polish Sejm (1), the Polish Senate (1), the Seimas of the Republic of Lithuania (2), the Danish Parliament (2), the Croatian Parliament (2), the Latvian Saeima (2) the Bulgarian National Assembly (2), the Hungarian National Assembly (2), the Estonian Parliament (2) and the National Council of the Slovak Republic (2) (Fromage, Kreilinger, 2017: 126).

They submitted a reasoned opinion, thereby triggering a subsidiarity check, the so-called yellow-card procedure. Most reasoned opinions deplored that the principle of "equal work for equal pay" would cause competitive disadvantage for their 
workers, that the applicability of collective agreements would then apply to all sectors instead of the construction sector only, and that Member States would lose their right to decide on the basic working and employment conditions of posted temporary agency workers as foreseen in the 2008 TAW Directive (The Briefing on the revision of the Posting of Workers Directive issued by the European Parliament). This yellow card procedure has been triggered twice since 2009, once on the right to strike in cross-border situations (the 'Monti II' proposal in 2012, which was subsequently withdrawn) and once on the establishment of a European Public Prosecutor's office (which was kept unchanged in 2013).

The Member States, regardless of the common EU policy based on shared competence, also run their own national policies, and it often leads to the impasse (Misiuna, Pachocka 2018: 230). In this case, also the positions of some opposing countries were similar to those presented by the Polish Senate, which presented the opinion (Opinion of the Senate of the Republic of Poland of 29 April 2016 on non-compliance with the subsidiarity principle of the draft directive of the European Parliament and of the Council amending Directive 96/71 / EC of the European Parliament and of the Council of 16 December 1996 concerning the posting of workers in the framework of the provision of services) that the Commission has not convincingly substantiated that in this case, full harmonization will contribute to better protection of workers. The opposing Member States argued that they could already independently shape the scope of subcontractors' obligations in this field, and the current wording of the directives allows them to reduce this scope in relation to service providers from other Member States. Representatives of entrepreneurs criticized this proposal from the European Commission as not justified in the context of improving social aspects or combating unfair practices but as a purely political initiative. In their opinion, it was also premature in the context of the ongoing implementation process of the so-called Implementation Directive 2014/67/EU (Directive 2014/67/EU of the European Parliament and of the Council of 15 May 2014 on the enforcement of Directive 96/71/EC concerning the posting of workers in the framework of the provision of services and amending Regulation (EU) No 1024/2012 on administrative cooperation through the Internal Market Information System - "the IMI Regulation").

To the alleged breach of the subsidiarity principle in the draft amendment to the Posted Workers Directive answered the President of the EC of that time, JeanClaude Juncker. In the face of resistance from many parliaments, it was emphasized that in this cross-border issue, it is necessary to resolve the matter at the European level and the opinion of the European Commission will be presented (The speech of Jean-Claude Juncker, President of the European Commission at the Conference of Speakers of the European Union Parliaments, 22-24 May 2016, Luxembourg). The 
Commission, after carrying out a subsidiarity review, in June 2016, decided that its proposal did not breach the subsidiarity principle and, therefore, maintained the proposal unchanged. As a consequence, on 29 May 2018, the European Parliament adopted the Amendment Directive.

\section{The issue of subsidiarity}

Before the adoption of the 1996 Directive, the CJEU emphasized that the provisions of the Treaty prevented the Member States from limiting the possibility of provision on its territory of services by entities from other countries that move with their employees to perform the service (such interpretation was presented, among others in the Case C-113/89 Rush Portuguesa Ld ${ }^{\mathrm{a}} \mathrm{v}$ Office national d'immigration, 1989).

Employees of a company temporarily directed to another Member State to provide services there do not in any way claim the right to access the labor market of that other country because they return to their country of origin or stay after carrying out their tasks (including the Case C-43/93 Raymond Vander Elst v Office des Migrations Internationales, 1993).

The purpose of Directive 96/71/EC was to remove obstacles and uncertainties related to the exercise of the freedom to provide services while ensuring appropriate employment standards. The paradox underlying the adoption of the Directive was described by Nils Wahl, Advocate General of the CJEU, in his opinion in the Case C-396/13 Sähköalojen ammattiliitto (Case C-396/13 Sähköalojen ammattiliitto ry v Elektrobudowa Spółka Akcyjna, 1913). It was stated that the Treaty provisions on the basis of which the Directive was enacted (Articles 57(2) and 66 EC) place an emphasis on the promotion of cross-border provision of services, the result of which is a directive which tips the balance in favor of the protection of domestic labor systems (Opinion of Advocate General Nils Wahl delivered on 18 September 2014, Case C-396/13 Sähköalojen ammattiliitto ry v Elektrobudowa Spółka Akcyjna; par. 30).

The issue of balancing between the "freedom to provide services" and "protection of national labor markets" has been to this day the axis of legal and political disputes that take place in the context of posting. The assessment of the social aspect of the Directive's regulation has long been the subject of divergence. The contentious issue was whether the Directive sets minimum standards that must be fulfilled in the Member States with the possibility of being extended by the Member States, or whether the Directive sets a ceiling for standards beyond which the Member States cannot go. The answer to this fundamental question was provided by the judgment of the CJEU in the Case C-341/05 Laval un Partneri (2005). The CJEU has determined 
that Directive 96/71 sets maximum standards that the Member States should not go beyond. Therefore, the provisions of the Directive cannot serve to introduce the obligation to pay higher than minimum rates. It has been widely accepted that in this judgment, priority was given to promoting the freedom to provide services in the interpretation of Directive 96/71.

It seems that the solutions adopted in the amending Directive are in contradiction with the essence of the treaty freedom to provide services. The changes introduced by the Commission do not lead to the achievement of the declared objectives of fairer remuneration and better employment conditions for posted workers, but de facto to the competitive exclusion from the European market of service providers providing their services using posted workers in other countries, by increasing their costs, level legal uncertainty and the imposition of additional barriers on them.

The Regulatory Impact Assessment (European Commission, Impact Assessment accompanying the document "Proposal for a Directive of the European Parliament and the Council amending Directive 96/71/EC concerning the posting of workers in the framework of the provision of services," COM (2016) 128 final) did not draw any conclusions from the fact that more than half of the delegations take place between countries with similar levels of pay and that the number of employees seconded by temporary employment agencies, which are largely responsible for so-called social dumping and unfair competition, is only about $5 \%$ of the total number of delegations.

It is also difficult to find justification for the abstract limitation of the duration of the service provided using posted workers in another Member State. Due to the provisions of the Treaty, it is not possible to specify the maximum duration of service in an abstract way. According to the case-law of the Court of Justice of the EU, services provided in another Member State under the freedom to provide services "may include services of a widely differing nature, including services that are provided for a long time, even for many years" (Case C-215/01 Bruno Schnitzer, 2001).

It can be expected that legal short-term labor mobility will be replaced by permanent migration and low-cost, illegally employed workers from the new Member States which joined the European Union in 2004 and later. It is likely that the blocked freedom to provide services will be supplanted by other economic freedoms, which will result in partial or total relocation of European enterprises to countries with low labor costs and greater availability of qualified labor force.

It seems that the posting of workers under relevant legislation is not a cause of social dumping. According to the report of the French Institute Jacques Delors, "Notre Europe" confirms that social competition in the EU in general, and especially between "new" and "old" Member States, is unlikely (Maslauskaité, 2013: 10). Statistical performance-adjusted nominal labor cost indicators show that "Opinions generally 
recognized as true regarding labor costs are no longer valid today" (Maslauskaite, 2013: 10). An important conclusion from the report is that if the nominal cost of labor is equalized, as a result of the principle of equal pay, its actual costs in the countries of Central and Eastern Europe will be the highest in Europe due to lower efficiency.

\section{Cases C-626/18 and C-620/18: Poland and Hungary v. the EP and the Council}

In October 2018, Poland (Case C-626/18 Republic of Poland v European Parliament and Council of the European Union, 2018) and Hungary (Case C-620/18 Hungary v European Parliament and Council of the European Union, 2018) lodged complaints with the CJEU. They demanded the annulment of the amendments adopted by the EP in June 2018 in whole or in part. Germany, France, the Netherlands, Sweden (in the Case C-626/18 only), and the Commission intervened in the proceedings in support of the Parliament and the EU Council. The complaint of Poland and Hungary against the European Parliament and the Council of the EU (as co-legislators in the field of EU law) concerned the changes in the rules for the posting of workers in the EU and were to enter into force from the end of July 2020.

In May 2020, Advocate General of the CJEU, Manuel Campos Sánchez-Bordony, in the issued Opinion C-626/18 Poland v. The EP and the Council (Opinion of Advocate General Manuel Campos Sanchez-Bordony delivered on 28 May 2020, Case C-626/18 Poland v. The EP and the Council), suggested that the Court should dismiss the actions for annulment brought by Poland against the Directive strengthening posted workers' rights. He delivered a similar Opinion on the same date in the case of a similar Hungarian complaint about the invalidity of the 2018/957 Review Directive (Opinion of Advocate General Manuel Campos Sanchez-Bordony delivered on 28 May 2020, Case C-620/18 Hungary v. The EP and the Council). In the Opinions, first, it is considered that the amending Directive was adopted using an appropriate legal basis. In that context, it is emphasized that, like Directive 96/71, the amending Directive pursues the twofold objective of, on the one hand, guaranteeing that undertakings are able to carry out the transnational provision of services by moving workers from their State of establishment and, on the other hand, of protecting the rights of posted workers and preventing unfair competition between undertakings, derived from the different levels of protection in the Member States.

It is acknowledged that most of the provisions of the amending Directive relate in particular to the protection of posted workers, which is due to the fact that the EU legislature considered that it was essential to amend Directive 96/71 in that sense 
in the light of the development of the EU employment markets following consecutive enlargements and the 2008 financial crisis. It is underlined that, when the EU legislature enacts a harmonizing provision, such as Directive 96/71, it cannot be denied the possibility of adapting that Act to a subsequent change in circumstances or development of events. Furthermore, the fact that the amending Directive is aimed primarily at protecting posted workers' rights does not mean that it ought to have been adopted on the basis of Article 153 TFEU, relating to certain aspects of the EU's social policy. In that regard, it is recalled that an act amending another earlier act will normally have the same legal basis as the amended rule.

Moreover, it is possible for Articles 53(1) TFEU and 62 TFEU, whose objective is to ensure freedom of establishment and the freedom to provide services, to be the appropriate legal basis for the amending Directive, as they were previously for Directive 96/71. The amending Directive simply coordinates the application of the concurrent employment legislation of the host State and State of origin, and does not, under any circumstances, set the level of wages to be paid, which comes within the competence of the Member States. Likewise, posted workers' remuneration will continue to differ in some respects from local workers' remuneration, with the result that the differences between the actual remuneration received by both types of workers will not be eliminated. For the same reason, it is considered that the competitive advantages of the undertakings of EU countries with lower labor costs which post workers to the Member States with higher labor costs will not be eliminated, either.

It is said that in adopting the amending Directive, the EU legislature complied with the requirements of the principle of proportionality without manifestly exceeding its broad discretion in the area of regulating the transnational posting of workers. The regulation of long-term posted workers (12 or 18 months) introduced by the amending Directive is justified and involves restrictions that are proportionate to the freedom to provide services, in as much as it is consistent with the situation of workers whose integration into the labor market of the host State is greater. The amending Directive also does not contain any substantive rules governing the posting of workers in the transport sector, and that it will apply to that sector only when a legislative act to that end is adopted in the future (Court of Justice of the European Union Press Release No 63/20, Luxembourg, 28 May 2020). In that respect, Hungary's argument, according to which the reference made by the amending Directive to that future legislative Act constitutes, in itself, an infringement of the provision of the FEU Treaty relating to the application of the principle of the free movement of services in the transport sector should be rejected (Article 58(1) TFEU).

The argument of the disproportionate nature of the principle of adding up the periods of posting introduced by Directive 2018/957 was also addressed. Interestingly, 
the General Advocate admitted that Poland was right, stating that "It is true that, as argued by the Polish government, there is some ambiguity in the wording of the said provision, as it does not set a time limit to add up the periods in which posted workers perform work in the same position." Apart from agreeing to the Polish argument, the General Advocate did not address many doubts accompanying the methods of summing these periods. It will not be considered the fact that there will be even more of them after the transposition of the Directive into the internal orders of the host countries. It also failed to take into account the argument suggested by Poland that measures already in place in EU law would be sufficient to protect against fraud. It is about the provisions on determining the actual posting and preventing abuse and circumvention of the provisions of Art. 4 of so-called Implementation Directive 2014/67. Instead, it is found that Poland has not demonstrated that there are other, less restrictive options to avoid fraudulent behavior in the context of the posting of workers. It is proposed that the plea of annulment be rejected in its entirety.

The Advocate General's Opinion is not binding on the CJEU. However, the final rulings of the European Court of Justice are in the overwhelming majority of cases consistent with the opinions of the CJEU advocates-general. In the light of the Opinion, it will not be easy for the Court to recognize Directive 2018/957 as incompatible with EU law. If the CJEU agreed to the request of Poland and Hungary, this would also indirectly affect the still finally unapproved reform of the rules on truck drivers in international transport, which the EU initially agreed in December 2019. Probably the CJEU will not be able to pass its judgment before the new regulations enter into force.

Poland, together with other Member States, is obliged to implement the amending Directive by 30 July 2020. But work on the amendment to the Act on the posting of workers as part of the provision of services of 10 June 2016 is ongoing, and it seems that it will not be completed by the end of July. The draft amendment to the Act provides for the implementation of the amending Directive into Polish law (Gwiazda, 2020).

Regardless of the fact worker mobility was significantly reduced in 2020 due to the Covid-19 pandemic, despite such a sudden change, employers posting employees abroad should be independently aware of the changes that took effect after 30 July 2020. Bearing in mind the fact that Poland is a leader in the cross-border posting of workers, changes in the legislation of the Member States arising from the implementation of the Directive would significantly affect Polish employers posting workers to EU countries. However, changes in the Polish law regulating the posting of workers to Poland will also affect the situation of the employers posting workers to Poland from other countries, such as Ukraine (Gwiazda, 2020). 


\section{Conclusion}

In conclusion, it should be considered that the Commission proposal pursues a purpose other than the declared one and thus, violates the principle of proportionality. It is contrary to the principle of subsidiarity because its objectives can be achieved more effectively by acting within the framework of national legal orders, e.g., by more effectively checking compliance with current rules. The implemented changes have been introduced to a large extent as a result of a misunderstanding of the delegation of employees and the attribution of the phenomenon to the scale and consequences of illegal work in the gray economy. It is still not known well how to calculate the long-term period of posting of workers regulated in the Directive. In addition, the provisions transposing it into the national legal orders make the interpretation of this issue even more difficult. It is clear that smart and clear rules are needed that are adapted to the rapidly growing mobility of EU businesses and citizens, which will prevent the progressive loss of competitiveness of the EU market, while accelerating social convergence and preventing illegal activities affecting intra-EU migrant workers, bearing in mind also the circumstances of the Covid-19 pandemic affecting the rapidly changing national legal regulations of the Member States regarding the possibility of the mobility of their citizens.

The analysis also shows that the division of competences between the Member States and EU institutions is ultimately a political decision that arises in the context of a conflict of interest. Economic analyses can only provide arguments for or against policy centralization. In addition, integration is a dynamic process, and, therefore, the results of the analysis regarding the justification for the application of the subsidiarity principle may change over time, as the conditions in which economies operate change dynamically.

\section{References}

Case C-113/89 Rush Portuguesa Ld ${ }^{\mathrm{a}} \mathrm{v}$ Office national d'immigration.

Case C-19/67 Soziale Verzekeringsbank v Van Der Vecht.

Case C-215/01 Bruno Schnitzer.

Case C-341/05 Laval un Partneri Ltd.

Case C-35/70 Manpower v Caisse primaire d'assurance maladie de Strasbourg.

Case C-396/13 Sähköalojen ammattiliitto ry v Elektrobudowa Spółka Akcyjna.

Case C-43/93 Raymond Vander Elst v Office des Migrations Internationales. 
Case C-620/18 Hungary v European Parliament and Council of the European Union.

Case C-626/18 Republic of Poland v European Parliament and Council of the European Union.

Ciancio, A. (2020). Why we could and should discuss about European constitutional law. In: A. Kłos, J. Misiuna, M. Pachocka, A. Szczerba-Zawada (Eds.), Connecting the European Union of shared aims, freedoms, values, and responsibilities. European Union and its values: freedom, solidarity, democracy: 9-16. Warsaw: CeDeWu.

Court of Justice of the European Union Press Release No 63/20, Luxembourg, 28 May 2020. Retrieved from: https://curia.europa.eu/jcms/upload/docs/application/pdf/2020-05/ cp200063en.pdf (accessed: 30.05.2020).

Directive 2014/67/EU of the European Parliament and of the Council of 15 May 2014 on the enforcement of Directive 96/71/EC concerning the posting of workers in the framework of the provision of services and amending Regulation (EU) No 1024/2012 on administrative cooperation through the Internal Market Information System ('the IMI Regulation') [2014] OJ L 159, 28.5.2014.

Directive No 2018/957 of the European Parliament and of the Council of 28 June 2018 amending Directive 96/71/EC concerning the posting of workers in the framework of the provision of services [2018] OJ L 173, 9.7.2018.

Directive No 96/71/EC of the European Parliament and of the Council of 16 December 1996 concerning the posting of workers in the framework of the provision of services [1996] OJ L 18, 21.1.1997.

European Commission, Impact Assessment accompanying the document "Proposal for a Directive of the European Parliament and the Council amending Directive 96/71/EC concerning the posting of workers in the framework of the provision of services," COM (2016) 128 final.

Fromage, D., Kreilinger, V. (2017). National parliaments' third yellow card and the struggle over the revision of the Posted Workers Directive. European Journal of Legal Studies, 10(1): 126.

Gelauff, G. (2008). Subsidiarity for Better Economic Reform? In: G. Gelauff, I. Grilo, A. Lejour (Eds.), Subsidiarity and Economic Reform in Europe: 1-18. Berlin, Heidelberg: Springer.

Gwiazda, A. (2020). Posting of workers after 30 July 2020 Legal Alert. Retrieved from: https://www. kochanski.pl/en/posting-of-workers-after-30-july-2020-legal-alert/ (accessed: 30.07.2020).

Lisicki, R. (2016). Analiza: Europejski spór o delegowanie pracowników. Retrieved from: http:// www.instytutobywatelski.pl/25303/komentarze/nauka-i-praca/analiza-europejski-spor-odelegowanie-pracownikow (accessed: 5.03.020).

Maslauskaitè, K. (2013). Social Competition in the EU: Myths and Realities. Jacques Delores Institute Notre Europe: 10.

Mataija, M. (2009). The Role of the National Parliaments. In: S. Rodin, T. Ćapeta, I. Goldner Lang (Eds.), Reform of the European Union - The Lisbon Treaty: 153. Zagreb: Narodne novine.

Misiuna, J., Pachocka, M. (2018). The EU and U.S. approaches towards irregular immigration. Studia Ekonomiczne. Zeszyty Naukowe Uniwersytetu Ekonomicznego w Katowicach, 372: 220-234.

Opinion of Advocate General Manuel Campos Sanchez-Bordony delivered on 28 May 2020, Case C-620/18 Hungary v. The EP and the Council, ECLI:EU:C:2020:392. 
Opinion of Advocate General Manuel Campos Sanchez-Bordony delivered on 28 May 2020, Case C-626/18 Poland v. The EP and the Council, ECLI:EU:C:2020:394.

Opinion of Advocate General Nils Wahl delivered on 18 September 2014, Case C-396/13 Sähköalojen ammattiliitto ry v Elektrobudowa Spółka Akcyjna; par. 30, ECLI:EU:C:2014:2236.

Opinion of the Senate of the Republic of Poland of 29 April 2016 on non-compliance with the subsidiarity principle of the draft directive of the European Parliament and of the Council amending Directive 96/71 / EC of the European Parliament and of the Council of 16 December 1996 concerning the posting of workers in the framework of the provision of services.

The Briefing on the revision of the Posting of Workers Directive issued by European Parliament. Retrieved from: https://www.europarl.europa.eu/RegData/etudes/BRIE/2017/607346/ IPOL_BRI\%282017\%29607346_EN.pdf (accessed: 19.03.2020).

Treaty on the Functioning of the European Union (Official Journal of the EU C 202 of 7.06.2016: 47).

van Hoek, A., Houwerzijl, M. (2012). 'Posting' and 'Posted Workers': The Need for Clear Definitions of Two Key Concepts of the Posting of Workers Directive. Cambridge Yearbook of European Legal Studies, 14: 419-451. 